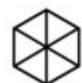 \\ LEUPHANA \\ UNIVERSITÄT LÜNEBURG
}

\section{Still different after all these years}

Wagner, Joachim

\author{
Publication date: \\ 2014
}

\section{Document Version}

Publisher's PDF, also known as Version of record

Link to publication

Citation for pulished version (APA):

Wagner, J. (2014). Still different after all these years: Extensive and intensive margins of exports in East and West German manufacturing enterprises. (Working Paper Series in Economics; No. 313). Institut für Volkswirtschaftslehre der Universität Lüneburg.

\section{General rights}

Copyright and moral rights for the publications made accessible in the public portal are retained by the authors and/or other copyright owners and it is a condition of accessing publications that users recognise and abide by the legal requirements associated with these rights.

- Users may download and print one copy of any publication from the public portal for the purpose of private study or research.

- You may not further distribute the material or use it for any profit-making activity or commercial gain

- You may freely distribute the URL identifying the publication in the public portal ?

Take down policy

If you believe that this document breaches copyright please contact us providing details, and we will remove access to the work immediately and investigate your claim. 


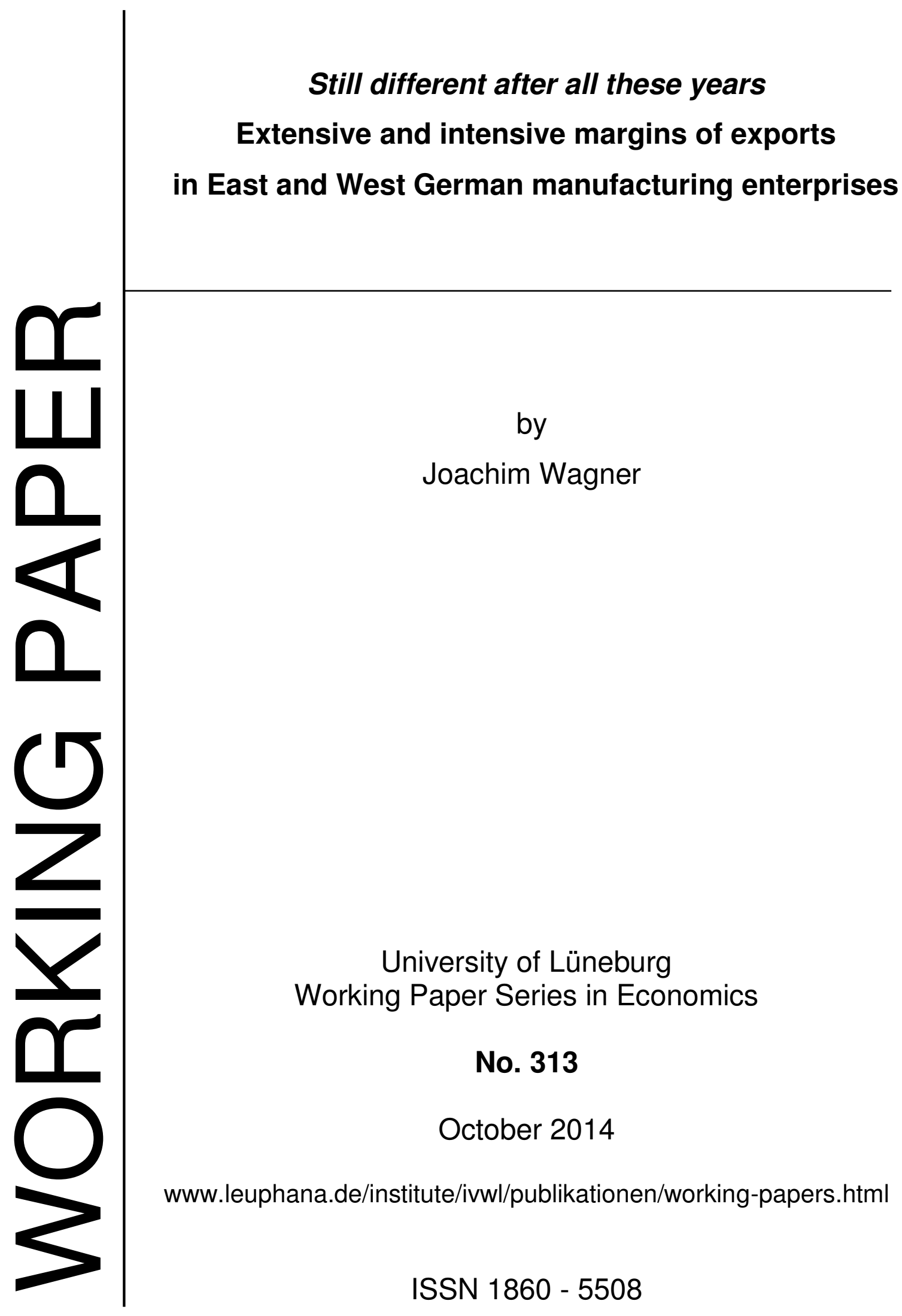




\title{
Still different after all these years
}

\section{Extensive and intensive margins of exports \\ in East and West German manufacturing enterprises*}

\author{
Joachim Wagner \\ Leuphana University Lueneburg, Germany, and CESIS, KTH Stockholm, Sweden
}

[This version: October 23, 2014]

Abstract:

This paper uses a new tailor-made data set to investigate the differences in extensive and intensive margins of exports in manufacturing firms from East Germany and West Germany. It documents that these margins do still differ in 2010, 20 years after the re-unification of Germany. West German firms outperform East German firms at all four margins of exports they have a larger propensity to export, export a larger share of total sales, export more goods and export to a larger number of countries. All these differences are large from an economic point of view. A decomposition analysis shows that in 2010 between 59 percent and 78 percent of the difference in margins can be explained by differences in firm characteristics. Most important here is the higher human capital intensity and (to a much lesser extent) the larger share of old firms in West Germany compared to East Germany.

Keywords: Export margins, East Germany, West Germany, decomposition analysis JEL Classification: F14

*All computations were done at the Research Data Centre of the Statistical Office of Berlin-
Brandenburg in Berlin. The firm-level data used are strictly confidential but not exclusive; see
http://www.forschungsdatenzentrum.de/datenzugang.asp for information on how to access the data.
To facilitate replications the Stata do-file used is available from the author on request. Many thanks to
Paul Simon for his inspiration for the title of the paper (see:
http://en.wikipedia.org/wiki/Still Crazy After All These Years \%28song\%29)

Prof. Dr. Joachim Wagner

Leuphana University Lueneburg

Institute of Economics

PO Box 2440

D-21314 Lueneburg, Germany

e-mail: wagner@leuphana.de

www: http://www.leuphana.de/joachim-wagner.html

phone: +49-4131-677-2330 


\section{Motivation}

Germany is one of the leading actors on the world market for goods and services. Exports play a key role in shaping the development of the German economy over the short and the long run. Given this decisive role of exports for the dynamics of the German economy it comes as a surprise that exports do play only a minor role in the discussion of persisting differences and convergence processes in the two parts of Germany today, 25 years after the re-unification of East and West Germany. While differences in growth, earnings, unemployment or life satisfaction between the two parts of Germany make headlines, differences in exports do not. A case in point is the most recent comprehensive annual report of the federal government on the state of German unification where exports are mentioned only in passing by pointing to the still lower share of exports in total sales in the East German manufacturing industry compared to West Germany (Bundesminsterium für Wirtschaft und Energie (BMWI) 2014 , p. 20f.) and to the importance of policy measures with a view to increase the internationalization of East German firms (ibid., p. 67).

While the difference in the share of exports in total sales (i.e., the difference in the intensive margin of exports) between East German and West German manufacturing industries is a widely known fact, information on the differences in the extensive margins of exports (i.e., the share of exporting firms in all firms, the number of different goods exported by exporting firms, and the number of destination countries exported to) is scarce. Furthermore, none of these studies investigate the reasons behind these differences in the four export margins empirically. ${ }^{1}$

\footnotetext{
1 See Wagner (2011a) for a survey of empirical studies on the links between exports and firm characteristics in Germany that were published up to 2011. Wagner (2008) applies a decomposition analysis, but only for the propensity to export, and the method does not allow the kind of detailed decomposition applied here in this paper. Descriptive evidence on differences in the number of goods
} 
This paper contributes to the literature by using a new tailor-made data set for manufacturing enterprises to document the differences in export margins between firms from both parts of Germany and to link these differences in margins to differences in firm characteristics. To anticipate the most important results we find that West German firms outperform East German firms at all four margins of exports - they have a larger propensity to export, export a larger share of total sales, export more goods and export to a larger number of countries. All these differences are large from an economic point of view. A decomposition analysis shows that in 2010 between 59 percent and 78 percent of the difference in margins can be explained by differences in firm characteristics. Most important here is the higher human capital intensity and (to a much lesser extent) the larger share of old firms in West Germany compared to East Germany.

The rest of the paper is organized as follows. Section 2 discusses the various data sets and the definition of variables that are used in the empirical investigations. Section 3 presents descriptive evidence for differences in the margins of exports in manufacturing enterprises in East and West Germany. Section 4 documents East / West differences in firm characteristics that are expected to be related to margins of exports. Section 5 reports results from an econometric investigation of the differences in the export margins between manufacturing firms from both parts of Germany. Section 6 concludes.

exported and the number of destination countries of exports in East and West German manufacturing firms is given in Wagner (2012a). 


\section{Data and definition of variables}

The empirical investigation uses a tailor-made data set that combines high quality firm-level data from four official sources. The first source of firm level information is the regular survey of establishments from manufacturing industries by the Statistical Offices of the German federal states. The survey (known as the Monatsbericht, or monthly report) covers all establishments from manufacturing industries that employ at least twenty persons in the local production unit or in the company that owns the unit. Participation of firms in the survey is mandated in official statistics (see Malchin and Voshage (2009) for details). For this study the monthly establishment data were aggregated to annual data and at the enterprise level to match the unit of observation in the other data sources (described below).

The second source of data is the cost structure survey for enterprises in the manufacturing sector. This survey is carried out annually as a representative random sample survey in about 15,000 firms. The sample is stratified according to the number of employees and the industries; all firms with 500 and more employees are covered by the cost structure survey (see Fritsch et al. 2004).

Information on the goods traded internationally is available from the statistic on foreign trade (Außenhandelsstatistik). This statistic is based on two sources. One source is the reports by German firms on transactions with firms from countries that are members of the European Union (EU); these reports are used to compile the socalled Intrahandelsstatistik on intra-EU trade. The other source is transaction-level data collected by the customs on trade with countries outside the EU (the so-called Extrahandelsstatistik). ${ }^{2}$ Data in the statistic of foreign trade are transaction-level data,

\footnotetext{
2 Note that firms with a value of imports from EU-countries that does not exceed 400,000 Euro do not have to report to the statistic on intra-EU trade. For trade with firms from non-member countries all
} 
i.e. they relate to one transaction of a German firm with a firm located outside Germany at a time. For the reporting year 2010 these transaction-level data have been aggregated at the level of the exporting firm (see Wagner 2014a). This dataset is the third source of data used in this study.

These data were matched with the enterprise register system (Unternehmensregister-System) and with the enterprise level data from the two other sources discussed above. The enterprise register system is used as the fourth source of data.

With these linked four data sets it is possible to investigate the differences in the margins of exports in manufacturing firms from East Germany and West Germany. The definition of the variables used in the empirical investigation is discussed in detail below.

The study looks at four different margins of exports, one intensive margin and three extensive margins:

Exporter status: The first extensive margin measures the participation of a firm in exports (or not).

Share of exports in total sales: The intensive margin of export is the percentage share of all sales due to exports.

Information on the exporter status of a firm and on the share of exports in total sales of a firm is based on information on export sales and total turnover taken from the first data source (the monthly report). This information is available for each year starting in 1995 and for all firms from manufacturing industries with at least twenty employees.

transactions that exceed 1,000 Euro are registered. For details see Statistisches Bundesamt, Qualitätsbericht Außenhandel, Januar 2011. 
Number of exported goods: The second extensive margin of exports is the number of different goods that a firm exported. A good is defined as an eight-digit number from the official nomenclature for the statistics of foreign trade.

Number of export destination countries: The third extensive margin is the number countries a firm exported to.

Information on the number of exported goods and the number of export destination countries is taken from the third source of data (the statistic on foreign trade). This information is available for each year starting in 2009; the most recent year the data were available when the computations for this paper were performed is 2010. Note that by construction this information is only available for exporting firms covered by the statistic on foreign trade, and for firms that were linked to the data from the monthly report (that are needed to distinguish between firms from East Germany and West Germany).

In the empirical investigation of the differences in the margins of exports between manufacturing firms from East and West Germany a number of firm characteristics are considered. The definition of the variables used in the empirical investigation is discussed in detail below.

Firm size: A positive link between firm size and margins of exports qualifies as a stylized fact. This positive link is due to fixed costs of exporting and efficiency advantages of larger firms due to scale economies, advantages of specialization in management and better conditions on the markets for inputs. Large firms can be expected to have cost advantages on credit markets while small firms often face higher restrictions on the capital market leading to a higher risk of insolvency and illiquidity. Furthermore, there might be disadvantages of small firms in the competition for highly qualified employees. There are limits to the advantage of size, because 
coordination costs mount as the scale of operations increases, and at some point any further expansion might cease to be profitable. Therefore, a positive relationship between firm size and exports, at least up to a point, is expected. For Germany empirical evidence in line with this is reported in a number of studies (see Wagner (2011a) for a survey). Firm size is measured here by the number of employees in a firm (also included in squares to take care of non-linearity). The source is the first data set (the monthly report).

Human capital intensity: Given that Germany is relatively rich in human capital, firms that use human capital intensively can be expected to have a comparative advantage on international markets. Empirical studies find that the qualification of the workforce is an important factor for the international competitiveness of German firms (Wagner 2011b). Human capital intensity is measured here by the average wage per employee. Direct information on the qualification of the employees in a firm is not available in the data used in this study, but Wagner (2012b) demonstrates that the average wage is indeed a good proxy variable for the qualification of the workforce in German manufacturing firms. The source is for information on the amount of wages paid and the number of employees is the first data set (the monthly report).

$R \& D$ intensity: Activities in research and development that are closely related to product and process innovations are known to be positively linked to success in exports in German firms (see Wagner (2011a, 2011b)). R\&D intensity is measured here by the share of employees that are active in R\&D in all employees in a firm. This intensity measure is based on information on R\&D employees and total employees taken from the second data source (the cost structure survey). 
Capital intensity: The amount of capital used per employee is traditionally expected to be positively liked to exports in a relatively capital-abundant country like Germany. In the data used in this study, however, there is no direct information on the capital stock of the firms. Therefore, the amount of depreciation per employee is used as a proxy variable that can be expected to be (more or less) proportional to the amount of capital per head. Information on the amount of depreciation and the number of employees is taken from the second data source (the cost structure survey).

Firm age: Although some newly founded firms are „born globals“ that export from the start, typically it takes years before firms eventually export to one foreign market, and then enter further markets progressively. Firms gain expertise in entering new foreign markets from experience, and this lowers the fixed costs of entry to any further new market. A similar argument can be made with regard to the number of products exported. At any point in time, therefore, firm age and the margins of exports can be expected to be closely linked. Germany is a case in point. Wagner (2014b) reports that older firms are more often exporters, export more and more different goods to more different destination countries. Information on firm age is not available from the data used in this study. However, we know whether a firm was already active in 1995 (the first year data from the monthly report are available for). Firms that were active in 1995, and that were founded before 1996 accordingly, are classified as old firms (based on this information from the first data source, the monthly report).

Foreign owned firm: Firms that are subsidies of a multinational enterprise that has its headquarter in a foreign country are termed foreign owned firms. Foreign ownership is known to have a positive impact on the margins of exports, because 
these firms can use the international networks and trade contacts of their parent companies and are involved in international supply chains (see Raff and Wagner (2014) for a discussion of the literature, a theoretical model, and empirical evidence for Germany). A firm is considered to be foreign owned if more than 50 percent of the voting rights of the owners or more than 50 percent of the shares are controlled (directly or indirectly) by a firm or a person/institution located outside Germany. Information on foreign ownership status of an enterprise is taken from the fourth source of data, the enterprise register system.

Industry: Dummy variables for 2digit-industries are included in the empirical models to control for industry specific effects like competitive pressure, policy measures, demand shocks etc. The source is the first data set (the monthly report).

\section{Descriptive evidence on differences in the margins of exports}

The empirical investigation of differences in the margins of export between enterprises from manufacturing industries in East and West Germany starts with showing that these differences do exist. Using information from the first source of data (the monthly report) Table 1 reports the share of exporters and the average share of exports in total sales among exporters in East and West Germany in four years, namely 1995 (the first year information is available for), 2001, 2006, and 2010 (the most recent year the information was available for when the computations for this study were performed).

The difference in the share of exporters (the first extensive margin investigated here) between East and West German firms was rather large in 1995 (some 25 percentage points). This difference declined over time, but it can still be considered to be large from an economic point of view in 2010 when it was nearly 14 percentage 
points. Note that this decline in the gap between both parts of Germany is not due a shrinking export participation in West Germany; the share of exporters grew in both parts, but the growth was more pronounced in East Germany.

The difference in the average share of exports in total sales among the exporters is remarkably stable (about 5 percentage points) over the years, and it is in favor of the West German firms. This difference is statistically highly significant not only at the mean (according to t-test) but over the whole distribution of the export/sales ratio (according to a Kolmogorov-Smirnov test for first-order stochastic dominance). Given that the average share of exports in total sales is 30 percent and 25 percent in West and East Germany in 2010, the size of the difference between firms from both parts of Germany can be considered to be large from an economic point of view. Note that the average share of exports in total sales increased considerably in both groups of firms.

[Table 1 near here]

Differences in exporting between East and West German firms are not limited to the propensity to export and to the export/sales ratio. Using information from the third source of data (the statistic on foreign trade) Table 2 reports that in 2010 both the number of exported goods (the second extensive margin of exports considered in this study) and the number of export destination countries (the third extensive margin) is considerably larger in West German firms than in East German firms. These differences are statistically highly significant not only at the mean (according to t-test) but over the whole distribution of the number of exported goods and the number of destination countries of exports (according to a Kolmogorov-Smirnov test 
for first-order stochastic dominance). Given that the average number of exported goods is 30 in West Germany and 15 in East Germany, the size of the difference between firms from both parts of Germany is large from an economic point of view. The same holds for the difference in the number of destination countries that is 7.5 countries with an average number of destination countries of 21.7 in West Germany and 14.2 in East Germany. ${ }^{3}$

[Table 2 near here]

The bottom line, then, is that West German firms outperform East German firms at all four margins of exports - they have a larger propensity to export, export more, more goods and to a larger number of countries. All these differences are large from an economic point of view.

\section{Differences in firm characteristics between East and West Germany}

The next step in the empirical investigation of differences in the margins of exports between East and West German manufacturing firms consists in reporting differences in firm characteristics that are expected to be related to margins of exports. Here we consider the following characteristics: Firm size, human capital intensity, R\&D intensity, capital intensity, firm age and foreign ownership. ${ }^{4}$

\footnotetext{
${ }^{3}$ Data from the statistics on foreign trade are available at the enterprise level for reporting years from 2009 onwards only. Therefore, changes over time in these extensive margins and in the differences between East and West Germany cannot be documented here.

${ }^{4}$ For a detailed definition of each characteristic, its measurement, and a discussion of the relation with exports see section 2 .
} 
Two of these characteristics (R\&D intensity and capital intensity) are based on information taken from the second data source, the cost structure survey. As said, this is a stratified sample of firms that covers some 15,000 manufacturing enterprises. All of these firms are covered in the monthly report, too, that is the source for information on three other firm characteristics, namely firm size, human capital intensity, and whether or not a firm is an old firm that existed in 1995 already. Furthermore, all these firms are in the enterprise register system that is the source of information on the foreign ownership status of the firm. The 14,716 firms with information from these three sources are in the estimation sample that is used to empirically investigate the differences in one extensive margin, the participation in exports, and in the intensive margin of exports (the share of exports in total sales).

Information on the two other extensive margins of exports, the number of goods exported and the number of countries exported to, is available only for a exporting firms. Matching firms with information on these extensive margins and information on the firm characteristics considered here reduces the sample of firms to $7,225 .{ }^{5}$

This leads to two different samples to be used in this descriptive part of the study, Sample $A$ (that covers 14,716 firms, 2,594 of which are from East Germany and 12,122 of which are from West Germany) and Sample $B$ (made of 7,225 firms, where 1,042 are from East Germany and 6,183 are form West Germany). Information on the average value of the firm characteristics for firms in each part of Germany is reported in Table 3 (for Sample A) and Table 4 (for Sample B).

\footnotetext{
57,225 is the number of firms with information on the number of goods exported. Information on the number of destination countries is available for 7,213 firms only.
} 


\section{[Table 3 near here]}

From Table 3 we see that in Sample $A$ firms in West Germany are considerably larger, have a higher intensity of human capital and lower capital intensity than East German firms. Furthermore, the proportion of old firms is larger in West Germany than in East Germany, while the share of foreign firms and the R\&D intensity is about the same in both parts of Germany. The picture is similar for firms from Sample $B$ (see Table 4) except that the difference in R\&D intensity and in the share of foreign owned firms is in favor of East German firms here.

\section{[Table 4 near here]}

\section{Econometric investigation of differences in East / West export margins}

The descriptive evidence reported so far documents that there are large differences in both the margins of exports and in firm characteristics related to exports between manufacturing firms from East and West Germany. To investigate the role of firm characteristics in shaping the differences in export margins the econometric study 6 proceeds in two steps.

Step one analyses whether differences in the export margins can still be observed after controlling for differences in the firm characteristics considered here.

\footnotetext{
${ }^{6}$ The econometric study is limited to the reporting year 2010. While information on export participation and on the share of exports in total sales is available for earlier years (see Table 1), information on important variables used in the econometric investigation is not: data on $R \& D$ is available from reporting year 1999 onwards only, information on foreign ownership starts in 2007, and the dummyvariable for old firms does not make (much) sense for 1995 and 2001. Furthermore, the sample used in the cost structure survey changed several times between 1995 and 2010, so that any comparison over time might be influenced by changes in the composition of the sample.
} 
Results reported in Table 5 and Table 6 reveal that this is indeed the case. Empirical models for each of the export margins that include the complete set of firm characteristics plus a dummy variable indicating whether a firm is from West Germany or not show a positive and statistically highly significant coefficient for being located in West Germany after controlling for firm characteristics. This holds for all four export margins, and for different estimation methods in the empirical model for export participation and the share of exports in total sales. ${ }^{7}$

[Table 5 and Table 6 near here]

Step two looks at the role of differences in characteristics between East and West German firms for the explanation of differences in the margins of exports. The approach applied here is a so-called decomposition technique. This type of empirical analysis that looks at differences in an outcome (e.g., the number of goods exported) between members of two groups (e.g., firms from East and West Germany) and that decomposes the difference into a part that is explained by differences in (observed) characteristics between members of the groups (e.g., by the difference in the average intensity of human capital or the different share of old firms in East and West German firms) and into a part that is due to differences in the coefficients that link firm characteristics to the outcome in a regression model between the two groups is widely used in in the social sciences. Some 40 years ago regression decomposition

\footnotetext{
7 Here the empirical models serve as a tool to demonstrate that East/ West differences in export margins are present after controlling for firm characteristics only. Therefore, we do not go into any detail to discuss the estimation results.
} 
has been introduced into the economics literature by Blinder (1973) and Oaxaca (1973), and it has been widely used ever since on a broad number of topics.

Recently, Powers et al. (2011) published a Stata command, mvdcmp, for carrying out multivariate decomposition for different types of models. A discussion of the details of the decomposition techniques used by this command is far beyond the scope of this applied paper. Suffice it to say here that one novel feature of mvdcmp that will be used here is that it provides a detailed decomposition (and standard errors) for the part of the difference of the outcome between the two groups of firms that is explained by differences in firm characteristics. To state it differently, mvdcmp reports the share of the difference in a margin of exports between East German an West German firms that can be explained by differences in the observed characteristics of the firms that are included in the empirical model for the margin, and it reports the share that each of these characteristics contributes to the explanation of the difference (plus the estimated standard error of this contribution). ${ }^{8}$

\subsection{Export participation}

At first, we look at the first extensive margin of exports, the decision to export or not. The empirical models for the participation in exports are estimated separately for East German and West German firms. The dependent variable in these models is a dummy variable that takes on the value of one for an exporting firm and that is zero

\footnotetext{
${ }^{8}$ Note that mvdcmp computes the same information for the part of the difference in a margin that is related to differences in the estimated coefficients. We focus here on the part that is due to observed firm characteristics and consider the part related to differences in the estimated coefficients as an unexplained part. Wagner (2008) is an earlier attempt to investigate the difference in one extensive margin, the propensity to export, for firms from East Germany and West Germany in 2004. In that paper, that uses a less rich data set, a different decomposition method is applied that does not provide a detailed decomposition.
} 
for a non-exporting firm. Two variants of these models are considered here. The first is estimated by OLS, applying a linear probability model (LPM), the second is estimated using Probit. While the critique of an application of LPM is well known from introductory textbooks on econometrics, it should be pointed out that "it often does a very good job" (Wooldridge 2010, p. 563). Note that the standard errors are based on estimates that are robust against heteroscedasticity. The use of the LPM is attractive here because this will be the basis for the decomposition analysis. ${ }^{9}$

Results for the empirical models are reported in Table 7. As expected, human capital intensity, R\&D intensity, firm age and foreign ownership status are positively related to export participation in both parts of Germany, while capital intensity is not and the link between firm size and export participation is only statistically significant at a usual level for West German firms.

[Table 7 near here]

Results for the decomposition of the difference in export participation between East and West German firms (that amounts to 11.61 percentage points in favor of West German firms in the sample used in the estimation) are reported in Table $8 .{ }^{10}$ More than two thirds of this difference is explained by differences in firm characteristics. Results for the detailed decomposition show that by far the most important characteristic is human capital intensity; one half of the difference in the

\footnotetext{
9 For a "defense" of the use of the LPM (with heterosecedasticity-robust standard errors) see Wooldridge (2010, p. 562f.).

10 Note that these results are based on the LPM estimates reported in Table 7. Due to numerically problems the mvdcmp program could not compute results from a decomposition based on the Probit estimates.
} 
propensity to export between East German and West German manufacturing firms is explained by higher human capital intensity in West Germany. The higher share of old firms that were founded before 1996 in West Germany explains 10.5 percent of the difference in the export propensity. All other characteristics do not matter.

[Table 8 near here]

\subsection{Share of exports in total sales}

Next, we look at the intensive margins of exports, the share of exports in total sales. The empirical models for the export / sales ratio are estimated separately for East German and West German firms. The dependent variable in these models is a percentage variable with a probability mass at zero due to many firms that do not export at all. An appropriate method to estimate an empirical model with this type of dependent variable is to use a fractional logit model (see Wagner (2001) for a discussion with a view to the export / sales ratio). However, given that OLS estimates often lead to the same conclusions, and with a view on the decomposition analysis, the empirical model is estimated by OLS, too.

Results for the empirical models are reported in Table 9. Firm size, human capital intensity, R\&D intensity and foreign ownership status are positively linked to export intensity as expected in firms from both parts of Germany. Firm age is only statistically significant among West German firms, while the same holds for capital intensity among East German firms only. These links are both positive as expected. Note that the coefficient estimates from the OLS models and the comparable average marginal effects based on the estimated coefficients from the fractional logit models tend to be rather similar. 


\section{[Table 9 near here]}

Results for the decomposition of the difference in export intensity between firms from both parts of Germany are reported in Table $10 .{ }^{11}$ More than three fourth of the difference of 6.8 percentage points (that is in favor of West German firms) is explained by differences in firm characteristics. Results for the detailed decomposition show that, like in the case of export participation, the lion's share of this is due to the higher human capital intensity of West German firms that explains more than two thirds of the difference in the average export / sales ratio. The contribution of the higher share of old firms in West Germany to the explanation of the difference in export intensity is about 4 percent. The other characteristics do not matter much.

[Table 10 near here]

\subsection{Number of destination countries of exports}

The third margin to look at is the number of destination countries of exports. Results for the empirical models for firms from East Germany and West Germany are reported in Table $11 .{ }^{12}$ The estimated coefficients point to positive links between all

\footnotetext{
11 Note that these results are based on the OLS estimates reported in Table 9, because the mvdcmp program cannot compute the decomposition based on the fractional logit estimates.

12 Although the dependent variable in the empirical models is a count variable that can only take positive integer values equal to or larger than one (because by construction only firms that export to at least one country are included in the sample) with a view on the decomposition analysis the models are estimated by OLS and not by using a count data model. The number of countries of destination is distributed over a rather broad range - the $99^{\text {th }}$ percentile of the distribution is 90 for West German
} 
firm characteristics and the number of countries exported to with the exception of the (insignificant) coefficients of capital intensity.

[Table 11 near here]

Results for the decomposition of the difference in in the number of destination countries between East and West German firms (that amounts to 9.5 countries in favor of West German firms in the sample used in the estimation) are reported in Table 12. About two thirds of this difference is explained by differences in firm characteristics. Results for the detailed decomposition show that one half of the difference in the number of destination countries is explained by higher human capital intensity in West Germany. The second largest impact is due to the higher share of old firms that were founded before 1996 in West Germany which explains 6.5 percent of the difference in the number of export countries.

[Table 12 near here]

\section{$5.4 \quad$ Number of goods exported}

The last margin of exports to be investigated is the number of goods exported. Results for the empirical models for East German and West German firms are reported in Table $13 .{ }^{13}$ The estimated coefficients point to positive links between the

firms and 71 for East German firms (the maximum number of countries is confidential because it refers to a single firm). This justifies the use of OLS in estimating the empirical models.

${ }^{13}$ Although the dependent variable in the empirical models is a count variable that can only take positive integer values equal to or larger than one (because by construction only firms that export at 
number of goods and firm size and human capital intensity in both parts of Germany, while R\&D intensity only matters for West Germany and capital intensity only matters (negatively) for East Germany. Firm age and foreign ownership status is not linked to this extensive export margin.

[Table 13 near here]

Results for the decomposition of the difference in in the number of exported goods between firms from East Germany and West German (that amounts to 21.3 goods in favor of West German firms in the sample used in the estimation) are reported in Table 14. About 60 percent of this difference is explained by differences in firm characteristics. According to the results for the detailed decomposition the difference in human capital intensity is again the by far most important factor to explain the difference. Here firm size matters, too, while other characteristics do not matter much (or not at all).

[Table 14 near here]

\section{Discussion}

This paper uses a new tailor-made data set to investigate the differences in extensive and intensive margins of exports in manufacturing firms from East Germany and

least one good are included in the sample) with a view on the decomposition analysis the models are estimated by OLS and not by using a count data model. The number of exported goods is distributed over a rather broad range - the 99th percentile of the distribution is 311 for West German firms and 186 for East German firms (the maximum number of goods is confidential because it refers to a single firm). This justifies the use of OLS in estimating the empirical models. 
West Germany. It documents that these margins do still differ in 2010, 20 years after the re-unification of Germany. West German firms outperform East German firms at all four margins of exports - they have a larger propensity to export, export a larger share of total sales, export more goods and export to a larger number of countries. All these differences are large from an economic point of view. A decomposition analysis shows that in 2010 between 59 percent and 78 percent of the difference in margins can be explained by differences in firm characteristics. Most important here is the higher human capital intensity and (to a much lesser extent) the larger share of old firms in West Germany compared to East Germany.

Should these findings considered to be stylized facts that can be used as a firm foundation to discuss any policy measures with a view to close the gap in the margins of exports between East and West Germany? I doubt. One reason is that the difference in the extensive margins related to the number of goods exported and the number of countries traded with is only documented for one year. This is due to the availability of data on these margins at the enterprise level (see section 2 above). There is no information about the size of these differences in the past or in more recent years. Furthermore, 2010 might well be considered as a "non-typical" year, because it is the year of the Great Export Recovery that followed the Great Export Recession during the world-wide great financial crisis in 2008/2009 (see Wagner (2013a, 2013b, 2014c) for empirical analyses of the export dynamics in Germany in both periods that use firm-level data). And it should be kept in mind that according to the decomposition analysis a considerable part of the difference in the export margins between manufacturing firms from East Germany and West Germany cannot be explained by differences in the observable firm characteristics that are considered in the empirical models. 
With a view on these caveats the bottom line of this empirical investigation can be stated as follows. There are sizeable differences in all margins of exports between manufacturing firms in East Germany and West Germany that are only rarely recognized in comparisons of the economy in both parts of Germany. These differences can only be documented and analyzed with combined firm level data from various sources from official statistics. These firm level data should be amended for more recent reporting years and be used to closely monitor the dynamics of export margins. This will contribute to a better understanding of the causes of differences in export margins and to a firm foundation for the discussion of any policy measures that aim to reduce these differences in margins.

\section{References}

Blinder, Alan S. (1973): Wage discrimination: Reduced form and structural estimates. Journal of Human Resources 8 (4), 436-455.

Bundesminsterium für Wirtschaft und Energie (BMWi) (2014): Jahresbericht der Bundesregierung zum Stand der Deutschen Einheit 2014. Berlin: BMWi.

Fritsch, Michael, Bernd Görzig, Ottmar Hennchen and Andreas Stephan (2004): Cost Structure Surveys for Germany. Schmollers Jahrbuch / Journal of Applied Social Science Studies 124 (4), 557-566.

Malchin, Anja and Ramona Voshage (2009): Official Firm Data for Germany. Schmollers Jahrbuch / Journal of Applied Social Science Studies 129 (3), 501513.

Oaxaca, Ronald (1073): Male-female wage differentials in urban labor markets. International Economic Review 14 (3), 693-709. 
Powers, Daniel A., Hirotoshi Yoshioka and Myeong-Su Yun (2011): mvdcomp: Multivariate decomposition for nonlinear response models. The Stata Journal 11 (4), 556-576.

Raff, Horst and Joachim Wagner (2014): Foreign Ownership and the Extensive Margins of Exports: Evidence for Manufacturing Enterprises in Germany. The World Economy 37 (5), 579-591.

Wagner, Joachim (2001): A Note on the Firm Size - Export Relationship. Small Business Economics 17 (4), 229-237.

Wagner, Joachim (2008): A note on why more West than East German firms export. International Economics and Economic Policy 5 (4), 363-370.

Wagner, Joachim (2011a): Exports and Firm Characteristics in Germany: A Survey of Empirical Studies (1991 to 2011). Applied Economics Quarterly 57 (2), 145160.

Wagner, Joachim (2011b): Exports and Firm Characteristics in German Manufacturing Industries: New Evidence from Representative Panel Data. Applied Economics Quarterly 57 (2), 107-143.

Wagner, Joachim (2012a): Trading many goods with many countries: Exporters and importers from German manufacturing industries. Review of Economics 63 (2), 170-186.

Wagner, Joachim (2012b): Average wage, qualification of the workforce and export performance in German enterprises: evidence from KombiFiD data. Journal of Labour Market Research 45 (2), 161-170.

Wagner, Joachim (2013a): The Granular Nature of the Great Export Collapse in German Manufacturing Industries, 2008/2009. Economics - The OpenAccess, Open-Assessment E-Journal 7 (5), 1-21. 
Wagner, Joachim (2013b): The Great Export Recovery in German Manufacturing Industries, 2009/2010. Review of Economics 64 (3), 325-339.

Wagner, Joachim (2014a): New Data from Official Statistics for Imports and Exports of Goods by German Enterprises. University of Lüneburg Working Paper Series in Economic No. 306 (forthcoming, Schmollers Jahrbuch / Journal of Applied Social Science Studies).

Wagner, Joachim (2014b): A note on firm age and the margins of exports: First evidence from Germany. University of Lüneburg Working Paper Series in Economic No. 303 (forthcoming, International Trade Journal).

Wagner, Joachim (2014c): The Role of Extensive Margins of Exports in The Great Export Recovery in Germany, 2009/2010. Jahrbücher für Nationalökonomie und Statistik / Journal of Economics and Statistics 234 (4), 518-526.

Wooldridge, Jeffrey M. (2010): Econometric Analysis of Cross Section and Panel Data. Second Edition. Cambridge, Massachusetts, and London, England: The MIT Press. 
Table 1: $\quad$ Margins of exports in enterprises from manufacturing industries in West and East Germany, Part I: Share of exporters and share of exports in total sales, 1995, 2001, 2006 and 2010

\begin{tabular}{|c|c|c|c|c|c|}
\hline & & 1995 & 2001 & 2006 & 2010 \\
\hline Number of firms & $\begin{array}{l}\text { West Germany } \\
\text { East Germany }\end{array}$ & $\begin{array}{r}33,865 \\
6,478\end{array}$ & $\begin{array}{r}34,007 \\
7,056\end{array}$ & $\begin{array}{r}31,482 \\
6,894\end{array}$ & $\begin{array}{r}27,992 \\
6,141\end{array}$ \\
\hline Share of exporters (percent) & $\begin{array}{l}\text { West Germany } \\
\text { East Germany }\end{array}$ & $\begin{array}{l}64.36 \\
39.13\end{array}$ & $\begin{array}{l}64.39 \\
44.35\end{array}$ & $\begin{array}{l}69.47 \\
52.61\end{array}$ & $\begin{array}{l}73.95 \\
60.14\end{array}$ \\
\hline Difference (percentage points) & & 25.23 & 20.04 & 16.86 & 13.81 \\
\hline Average share of exports in total sales among exporters (percent) & $\begin{array}{l}\text { West Germany } \\
\text { East Germany }\end{array}$ & $\begin{array}{l}21.94 \\
16.92\end{array}$ & $\begin{array}{l}26.46 \\
20.96\end{array}$ & $\begin{array}{l}29.91 \\
24.69\end{array}$ & $\begin{array}{c}30.05 \\
24.81\end{array}$ \\
\hline Difference (percentage points) & & 5.02 & 5.50 & 5.22 & 5.24 \\
\hline t-Test for $\mathrm{H}_{0}$ : Difference $=0$ (prob-value) & & 0.000 & 0.000 & 0.000 & 0.000 \\
\hline \multicolumn{6}{|l|}{ Kolmogorov-Smirnov -tests (prob-values) } \\
\hline $\begin{array}{l}\mathrm{H}_{0} \text { : Distributions do not differ between West and East } \\
\mathrm{H}_{0} \text { : Larger values in East compared to West } \\
\mathrm{H}_{0} \text { : Larger values in West compared to East }\end{array}$ & & $\begin{array}{l}0.000 \\
0.000 \\
0.998\end{array}$ & $\begin{array}{l}0.000 \\
0.000 \\
0.980\end{array}$ & $\begin{array}{l}0.000 \\
0.000 \\
0.936\end{array}$ & $\begin{array}{l}0.000 \\
0.000 \\
0.946\end{array}$ \\
\hline
\end{tabular}


Table 2: $\quad$ Margins of exports in enterprises from manufacturing industries in West and East Germany, Part II: Number of exported goods and number of destination countries, 2010

\section{Number of firms}

\section{Average number of exported goods}

Difference (number of exported goods)

$\mathrm{t}$-Test for $\mathrm{H}_{0}$ : Difference $=0$ (prob-value)

Kolmogorov-Smirnov -tests (prob-values)

$\mathrm{H}_{0}$ : Distributions do not differ between West and East

$\mathrm{H}_{0}$ : Larger values in East compared to West

$\mathrm{H}_{0}$ : Larger values in West compared to East
West Germany

East Germany

West Germany

East Germany

14.40
11,972

1,924

29.25

14.85

0.000

0.000

0.000

1.000

\section{Number of firms}

\section{Average number of export destination countries}

Difference (number of destination countries)

$\mathrm{t}$-Test for $\mathrm{H}_{0}$ : Difference $=0$ (prob-value)

Kolmogorov-Smirnov -tests (prob-values)

$\mathrm{H}_{0}$ : Distributions do not differ between West and East

$\mathrm{H}_{0}$ : Larger values in East compared to West

$\mathrm{H}_{0}$ : Larger values in West compared to East
West Germany

East Germany

West Germany

East Germany
11,455

1,928

21.68

14.16

0.000

0.000

0.000

0.999 
Table 3: $\quad$ Difference in characteristics in enterprises from manufacturing industries in East and West Germany 2010: Sample A

\begin{tabular}{|c|c|c|c|}
\hline & East & & West \\
\hline Number of enterprises & 2,594 & & 12,122 \\
\hline Firm size (no. of employees) & 178.11 & & 277.51 \\
\hline $\mathrm{t}$-Test for H0: Difference in means $=0$ (prob-value) & & 0.001 & \\
\hline \multicolumn{4}{|l|}{ Kolmogorov-Smirnov-tests (prob-value) } \\
\hline H0: Distributions do not differ & & 0.000 & \\
\hline HO: Larger values in East Germany & & 0.000 & \\
\hline H0: Larger values in West Germany & & 1.000 & \\
\hline Human capital intensity (wage per employee; $€$ ) & 25,454 & & 34,975 \\
\hline $\mathrm{t}$-Test for H0: Difference in means $=0$ (prob-value) & & 0.000 & \\
\hline \multicolumn{4}{|l|}{ Kolmogorov-Smirnov-tests (prob-value) } \\
\hline H0: Distributions do not differ & & 0.000 & \\
\hline H0: Larger values in East Germany & & 0.000 & \\
\hline H0: Larger values in West Germany & & 0.999 & \\
\hline R\&D intensity (share of R\&D employees; percent) & 2.66 & & 2.47 \\
\hline $\mathrm{t}-\mathrm{Test}$ for H0: Difference in means $=0$ (prob-value) & & 0.190 & \\
\hline \multicolumn{4}{|l|}{ Kolmogorov-Smirnov-tests (prob-value) } \\
\hline H0: Distributions do not differ & & 0.001 & \\
\hline HO: Larger values in East Germany & & 0.001 & \\
\hline H0: Larger values in West Germany & & 0.433 & \\
\hline Capital intensity (depreciations per employees; $€$ ) & 7,791 & & 5,362 \\
\hline $\mathrm{t}$-Test for H0: Difference in means $=0$ (prob-value) & & 0.000 & \\
\hline \multicolumn{4}{|l|}{ Kolmogorov-Smirnov-tests (prob-value) } \\
\hline H0: Distributions do not differ & & 0.000 & \\
\hline H0: Larger values in East Germany & & 1.000 & \\
\hline HO: Larger values in West Germany & & 0.000 & \\
\hline Share of firms founded before 1996 (percent) & 38.74 & & 55.81 \\
\hline Share of foreign owned firms (percent) & 13.11 & & 13.93 \\
\hline
\end{tabular}

Note: Entries for firm characteristics are average values for firms in the sample. 
Table 4: Difference in characteristics in enterprises from manufacturing industries in East and West Germany 2010: Sample B

\begin{tabular}{|c|c|c|c|}
\hline & East & & West \\
\hline Number of enterprises & 1,042 & & 6,183 \\
\hline Firm size (no. of employees) & 248.41 & & 315.65 \\
\hline $\mathrm{t}$-Test for H0: Difference in means $=0$ (prob-value) & & 0.324 & \\
\hline \multicolumn{4}{|l|}{ Kolmogorov-Smirnov-tests (prob-value) } \\
\hline H0: Distributions do not differ & & 0.000 & \\
\hline HO: Larger values in East Germany & & 0.000 & \\
\hline H0: Larger values in West Germany & & 0.987 & \\
\hline Human capital intensity (wage per employee; $€$ ) & 27,780 & & 36,491 \\
\hline $\mathrm{t}$-Test for H0: Difference in means $=0$ (prob-value) & & 0.000 & \\
\hline \multicolumn{4}{|l|}{ Kolmogorov-Smirnov-tests (prob-value) } \\
\hline H0: Distributions do not differ & & 0.000 & \\
\hline H0: Larger values in East Germany & & 0.000 & \\
\hline H0: Larger values in West Germany & & 0.998 & \\
\hline R\&D intensity (share of R\&D employees; percent) & 3.83 & & 2.94 \\
\hline $\mathrm{t}$-Test for H0: Difference in means $=0$ (prob-value) & & 0.000 & \\
\hline \multicolumn{4}{|l|}{ Kolmogorov-Smirnov-tests (prob-value) } \\
\hline H0: Distributions do not differ & & 0.015 & \\
\hline H0: Larger values in East Germany & & 1.000 & \\
\hline H0: Larger values in West Germany & & 0.007 & \\
\hline Capital intensity (depreciations per employees; $€$ ) & 9,262 & & 5,748 \\
\hline $\mathrm{t}$-Test for H0: Difference in means $=0$ (prob-value) & & 0.000 & \\
\hline \multicolumn{4}{|l|}{ Kolmogorov-Smirnov-tests (prob-value) } \\
\hline H0: Distributions do not differ & & 0.000 & \\
\hline H0: Larger values in East Germany & & 1.000 & \\
\hline H0: Larger values in West Germany & & 0.000 & \\
\hline Share of firms founded before 1996 (percent) & 42.99 & & 61.07 \\
\hline Share of foreign owned firms (percent) & 18.14 & & 15.67 \\
\hline
\end{tabular}

Note: Entries for firm characteristics are average values for firms in the sample. 
Table 5: $\quad$ Empirical models for the margins of exports in enterprises from manufacturing industries in Germany 2010: Export participation and share of exports in total sales

\begin{tabular}{|c|c|c|c|c|c|}
\hline & & \multicolumn{2}{|c|}{ Export participation } & \multicolumn{2}{|c|}{ Share of exports in total sales } \\
\hline & & OLS & Probit & OLS & Fractional logit \\
\hline $\begin{array}{l}\text { West Germany } \\
\text { (Dummy; } 1 \text { = yes) }\end{array}$ & $\begin{array}{l}\beta \\
p\end{array}$ & $\begin{array}{l}0.041 \\
0.000\end{array}$ & $\begin{array}{l}0.140 \\
0.000\end{array}$ & $\begin{array}{l}0.021 \\
0.000\end{array}$ & $\begin{array}{l}0.142 \\
0.000\end{array}$ \\
\hline $\begin{array}{l}\text { Firm size } \\
\text { (No. of employees) }\end{array}$ & $\begin{array}{l}\beta \\
p\end{array}$ & $\begin{array}{l}5.37 e-6 \\
0.023\end{array}$ & $\begin{array}{l}0.00041 \\
0.005\end{array}$ & $\begin{array}{l}0.000021 \\
0.000\end{array}$ & $\begin{array}{l}0.00011 \\
0.000\end{array}$ \\
\hline $\begin{array}{l}\text { Firm size } \\
\text { (squared) }\end{array}$ & $\begin{array}{l}\beta \\
p\end{array}$ & $\begin{array}{l}-5.70 \mathrm{e}-11 \\
0.018\end{array}$ & $\begin{array}{l}-3.22 e-9 \\
0.004\end{array}$ & $\begin{array}{l}-1.78 e-10 \\
0.000\end{array}$ & $\begin{array}{l}-8.68 \mathrm{e}-10 \\
0.000\end{array}$ \\
\hline $\begin{array}{l}\text { Human capital } \\
\text { (Wage per employee) }\end{array}$ & $\begin{array}{l}\beta \\
\mathrm{p}\end{array}$ & $\begin{array}{l}5.75 \mathrm{e}-6 \\
0.000\end{array}$ & $\begin{array}{l}0.000026 \\
0.000\end{array}$ & $\begin{array}{l}6.11 \mathrm{e}-11 \\
0.000\end{array}$ & $\begin{array}{l}0.000034 \\
0.000\end{array}$ \\
\hline $\begin{array}{l}\text { R\&D intensity } \\
\text { (Share of employees) }\end{array}$ & $\begin{array}{l}\beta \\
p\end{array}$ & $\begin{array}{l}0.429 \\
0.000\end{array}$ & $\begin{array}{l}4.702 \\
0.000\end{array}$ & $\begin{array}{l}0.544 \\
0.000\end{array}$ & $\begin{array}{l}2.369 \\
0.000\end{array}$ \\
\hline $\begin{array}{l}\text { Capital intensity } \\
\text { (Depreciation / empl.) }\end{array}$ & $\begin{array}{l}\beta \\
p\end{array}$ & $\begin{array}{l}6.91 \mathrm{e}-7 \\
0.088\end{array}$ & $\begin{array}{l}-3.55 \mathrm{e}-7 \\
0.861\end{array}$ & $\begin{array}{l}5.99 \mathrm{e}-7 \\
0.070\end{array}$ & $\begin{array}{l}4.21 \mathrm{e}-6 \\
0.019\end{array}$ \\
\hline $\begin{array}{l}\text { Old firm (Dummy) } \\
(1=\text { founded < 1996) }\end{array}$ & $\begin{array}{l}\beta \\
p\end{array}$ & $\begin{array}{l}0.067 \\
0.000\end{array}$ & $\begin{array}{l}0.244 \\
0.000\end{array}$ & $\begin{array}{l}0.018 \\
0.000\end{array}$ & $\begin{array}{l}0.130 \\
0.000\end{array}$ \\
\hline $\begin{array}{l}\text { Foreign owned firm } \\
\text { (Dummy; } 1=\text { yes) }\end{array}$ & $\begin{array}{l}\beta \\
\mathrm{p}\end{array}$ & $\begin{array}{l}0.062 \\
0.000\end{array}$ & $\begin{array}{l}0.361 \\
0.000\end{array}$ & $\begin{array}{l}0.117 \\
0.000\end{array}$ & $\begin{array}{l}0.550 \\
0.000\end{array}$ \\
\hline Industry controls & & yes & yes & yes & yes \\
\hline Number of firms & & 14,716 & 14,716 & 14,716 & 14,716 \\
\hline
\end{tabular}

Note: $\beta$ is the estimated regression coefficient and $p$ is the prob-value. All models include a constant; standard errors are based on robust estimates. 
Table 6: $\quad$ Empirical models for the margins of exports in enterprises from manufacturing industries in Germany 2010: Number of destination countries and number of goods exported

\begin{tabular}{|c|c|c|c|}
\hline & & $\begin{array}{l}\text { Number of destination countries } \\
\text { OLS }\end{array}$ & $\begin{array}{l}\text { Number of goods exported } \\
\text { OLS }\end{array}$ \\
\hline $\begin{array}{l}\text { West Germany } \\
\text { (Dummy; } 1=\text { yes) }\end{array}$ & $\begin{array}{l}\beta \\
\mathrm{p}\end{array}$ & $\begin{array}{l}3.811 \\
0.000\end{array}$ & $\begin{array}{l}9.144 \\
0.000\end{array}$ \\
\hline $\begin{array}{l}\text { Firm size } \\
\text { (No. of employees) }\end{array}$ & $\begin{array}{l}\beta \\
\mathrm{p}\end{array}$ & $\begin{array}{l}0.0076 \\
0.000\end{array}$ & $\begin{array}{l}0.0477 \\
0.000\end{array}$ \\
\hline $\begin{array}{l}\text { Firm size } \\
\text { (squared) }\end{array}$ & $\begin{array}{l}\beta \\
\mathrm{p}\end{array}$ & $\begin{array}{l}-5.76 e-8 \\
0.000\end{array}$ & $\begin{array}{l}-2.90 e-7 \\
0.000\end{array}$ \\
\hline $\begin{array}{l}\text { Human capital } \\
\text { (Wage per employee) }\end{array}$ & $\begin{array}{l}\beta \\
\mathrm{p}\end{array}$ & $\begin{array}{l}0.00053 \\
0.000\end{array}$ & $\begin{array}{l}0.00086 \\
0.000\end{array}$ \\
\hline $\begin{array}{l}\text { R\&D intensity } \\
\text { (Share of employees) }\end{array}$ & $\begin{array}{l}\beta \\
\mathrm{p}\end{array}$ & $\begin{array}{l}30.527 \\
0.000\end{array}$ & $\begin{array}{l}114.29 \\
0.000\end{array}$ \\
\hline $\begin{array}{l}\text { Capital intensity } \\
\text { (Depreciation / empl.) }\end{array}$ & $\begin{array}{l}\beta \\
\mathrm{p}\end{array}$ & $\begin{array}{l}-0.000058 \\
0.066\end{array}$ & $\begin{array}{l}-0.00022 \\
0.129\end{array}$ \\
\hline $\begin{array}{l}\text { Old firm (Dummy) } \\
(1=\text { founded < 1996) }\end{array}$ & $\begin{array}{l}\beta \\
\mathrm{p}\end{array}$ & $\begin{array}{l}3.415 \\
0.000\end{array}$ & $\begin{array}{l}1.362 \\
0.351\end{array}$ \\
\hline $\begin{array}{l}\text { Foreign owned firm } \\
\text { (Dummy; } 1=\text { yes) }\end{array}$ & $\begin{array}{l}\beta \\
\mathrm{p}\end{array}$ & $\begin{array}{l}2.341 \\
0.001\end{array}$ & $\begin{array}{l}-0.547 \\
0.819\end{array}$ \\
\hline Industry controls & & yes & yes \\
\hline Number of firms & & 7,225 & 7,213 \\
\hline
\end{tabular}

Note: $\beta$ is the estimated regression coefficient and $p$ is the prob-value. All models include a constant; standard errors are based on robust estimates. 
Table 7: Determinants of margins of exports in enterprises from manufacturing industries in East and West Germany 2010: Export participation

\begin{tabular}{|c|c|c|c|c|c|}
\hline & & \multicolumn{2}{|c|}{ Linear Probability Model } & \multicolumn{2}{|c|}{ Probit (Average Marginal Effects) } \\
\hline & & East & West & East & West \\
\hline Firm size & $ß$ & $0.232 \mathrm{e}-4$ & $6.51 e-6$ & & \\
\hline (No. of employees) & $\mathrm{p}$ & 0.194 & 0.011 & $0.00012^{1}$ & $0.878 \mathrm{e}-41$ \\
\hline $\begin{array}{l}\text { Firm size } \\
\text { (squared) }\end{array}$ & $\begin{array}{l}\beta \\
\mathrm{p}\end{array}$ & $\begin{array}{l}-3.72 \mathrm{e}-10 \\
0.187\end{array}$ & $\begin{array}{l}-6.45 \mathrm{e}-11 \\
0.009\end{array}$ & 0.080 & 0.011 \\
\hline $\begin{array}{l}\text { Human capital } \\
\text { (Wage per employee) }\end{array}$ & $\begin{array}{l}\beta \\
\mathrm{p}\end{array}$ & $\begin{array}{l}4.96 e-06 \\
0.000\end{array}$ & $\begin{array}{l}6.04 \mathrm{e}-6 \\
0.000\end{array}$ & $\begin{array}{l}5.93 e-6 \\
0.000\end{array}$ & $\begin{array}{l}5.74 \mathrm{e}-6 \\
0.000\end{array}$ \\
\hline $\begin{array}{l}\text { R\&D intensity } \\
\text { (Share of employees) }\end{array}$ & $\begin{array}{l}\beta \\
\mathrm{p}\end{array}$ & $\begin{array}{l}0.862 \\
0.000\end{array}$ & $\begin{array}{l}0.293 \\
0.000\end{array}$ & $\begin{array}{l}1.586 \\
0.000\end{array}$ & $\begin{array}{l}0.917 \\
0.000\end{array}$ \\
\hline $\begin{array}{l}\text { Capital intensity } \\
\text { (Depreciation / empl.) }\end{array}$ & $\begin{array}{l}\beta \\
\mathrm{p}\end{array}$ & $\begin{array}{l}1.18 \mathrm{e}-6 \\
0.075\end{array}$ & $\begin{array}{l}4.49 \mathrm{e}-7 \\
0.382\end{array}$ & $\begin{array}{l}8.44 e-7 \\
0.346\end{array}$ & $\begin{array}{l}-3.57 e-7 \\
0.514\end{array}$ \\
\hline $\begin{array}{l}\text { Old firm (Dummy) } \\
(1=\text { founded < 1996) }\end{array}$ & $\begin{array}{l}\beta \\
\mathrm{p}\end{array}$ & $\begin{array}{l}0.040 \\
0.019\end{array}$ & $\begin{array}{l}0.071 \\
0.000\end{array}$ & $\begin{array}{l}0.030 \\
0.078\end{array}$ & $\begin{array}{l}0.061 \\
0.000\end{array}$ \\
\hline $\begin{array}{l}\text { Foreign owned firm } \\
\text { (Dummy; } 1 \text { = yes) }\end{array}$ & $\begin{array}{l}\beta \\
\mathrm{p}\end{array}$ & $\begin{array}{l}0.114 \\
0.000\end{array}$ & $\begin{array}{l}0.052 \\
0.000\end{array}$ & $\begin{array}{l}0.120 \\
0.000\end{array}$ & $\begin{array}{l}0.064 \\
0.000\end{array}$ \\
\hline Industry controls & & yes & yes & yes & yes \\
\hline Number of firms & & 2,594 & 12,122 & 2,594 & 12,122 \\
\hline
\end{tabular}

1 The average marginal effect for firm size takes into account that firm size is included in the model in squares, too.

Note: All models include a constant; standard errors are based on robust estimates. 
Table 8: Decomposition of difference in the margins of exports in enterprises from manufacturing industries in East and West Germany 2010: Export participation

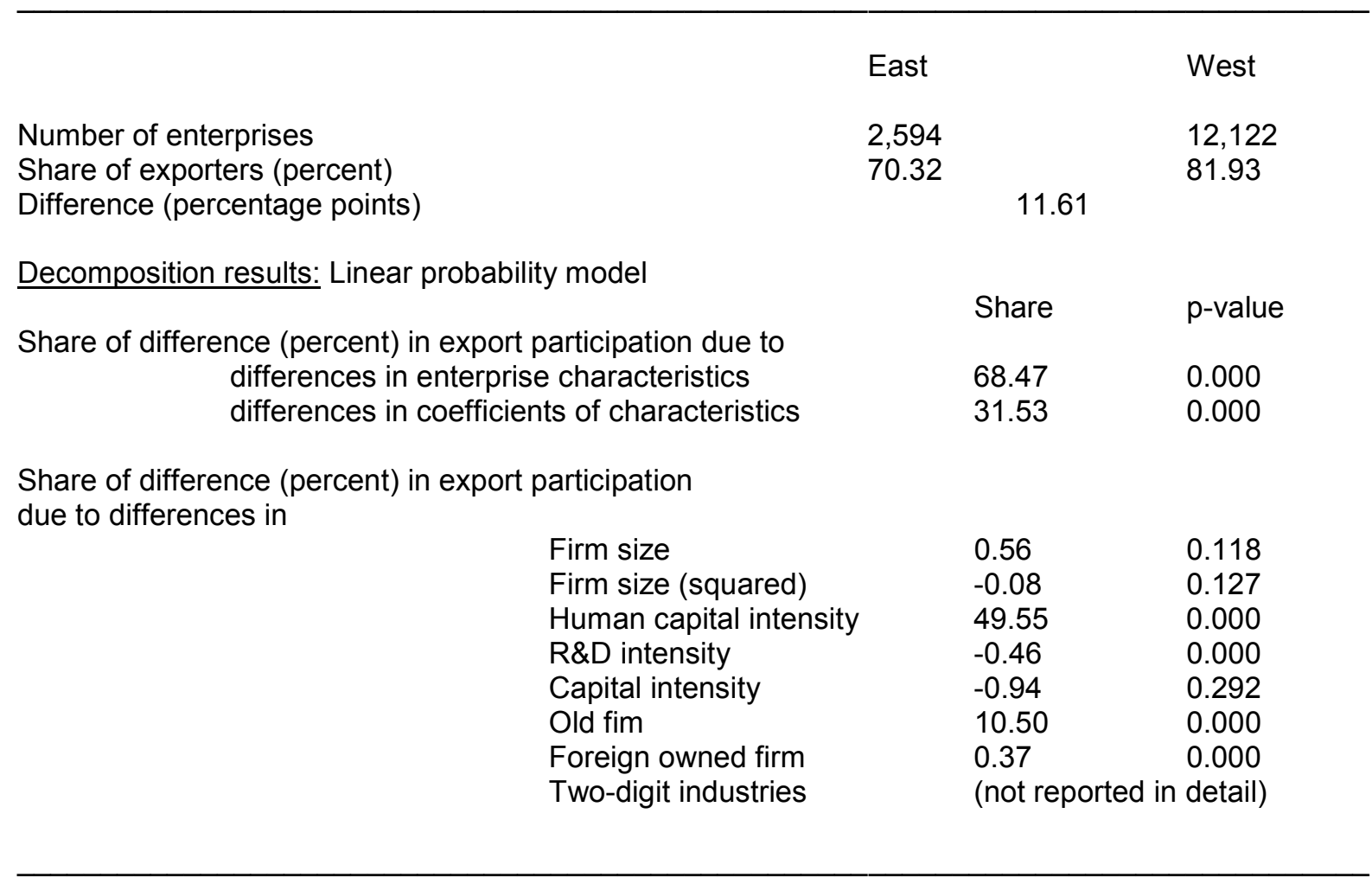

Note: The decomposition is based on the estimates reported in Table 7 
Table 9: Determinants of margins of exports in enterprises from manufacturing industries in East and West Germany 2010: Share of exports in sales

\begin{tabular}{|c|c|c|c|c|c|}
\hline & & \multicolumn{2}{|l|}{ OLS } & \multicolumn{2}{|c|}{$\begin{array}{l}\text { Fractional logit } \\
\text { (Average Marginal Effects) }\end{array}$} \\
\hline & & East & West & East & West \\
\hline Firm size & ß & $0.55 \mathrm{e}-4$ & $0.21 e-4$ & & \\
\hline (No. of employees) & $\mathrm{p}$ & 0.000 & 0.000 & $0.000033^{1}$ & $0.000019^{1}$ \\
\hline $\begin{array}{l}\text { Firm size } \\
\text { (squared) }\end{array}$ & $\begin{array}{l}\beta \\
p\end{array}$ & $\begin{array}{l}-7.74 \mathrm{e}-10 \\
0.000\end{array}$ & $\begin{array}{l}-1.70 \mathrm{e}-10 \\
0.000\end{array}$ & 0.000 & 0.000 \\
\hline $\begin{array}{l}\text { Human capital } \\
\text { (Wage per employee) }\end{array}$ & $\begin{array}{l}\beta \\
p\end{array}$ & $\begin{array}{l}5.47 e-6 \\
0.000\end{array}$ & $\begin{array}{l}6.14 \mathrm{e}-6 \\
0.000\end{array}$ & $\begin{array}{l}4.84 \mathrm{e}-6 \\
0.000\end{array}$ & $\begin{array}{l}6.00 \mathrm{e}-6 \\
0.000\end{array}$ \\
\hline $\begin{array}{l}\text { R\&D intensity } \\
\text { (Share of employees) }\end{array}$ & $\begin{array}{l}\beta \\
\mathrm{p}\end{array}$ & $\begin{array}{l}0.465 \\
0.000\end{array}$ & $\begin{array}{l}0.584 \\
0.000\end{array}$ & $\begin{array}{l}0.330 \\
0.000\end{array}$ & $\begin{array}{l}0.433 \\
0.000\end{array}$ \\
\hline $\begin{array}{l}\text { Capital intensity } \\
\text { (Depreciation / empl.) }\end{array}$ & $\begin{array}{l}\beta \\
\mathrm{p}\end{array}$ & $\begin{array}{l}1.19 \mathrm{e}-6 \\
0.005\end{array}$ & $\begin{array}{l}1.97 \mathrm{e}-7 \\
0.641\end{array}$ & $\begin{array}{l}9.81 \mathrm{e}-7 \\
0.009\end{array}$ & $\begin{array}{l}-3.60 \mathrm{e}-7 \\
0.353\end{array}$ \\
\hline $\begin{array}{l}\text { Old firm (Dummy) } \\
(1=\text { founded < 1996) }\end{array}$ & $\begin{array}{l}\beta \\
p\end{array}$ & $\begin{array}{l}-0.006 \\
0.497\end{array}$ & $\begin{array}{l}0.022 \\
0.000\end{array}$ & $\begin{array}{l}-0.001 \\
0.868\end{array}$ & $\begin{array}{l}0.026 \\
0.000\end{array}$ \\
\hline $\begin{array}{l}\text { Foreign owned firm } \\
\text { (Dummy; } 1=\text { yes) }\end{array}$ & $\begin{array}{l}\beta \\
\mathrm{p}\end{array}$ & $\begin{array}{l}0.152 \\
0.000\end{array}$ & $\begin{array}{l}0.111 \\
0.000\end{array}$ & $\begin{array}{l}0.134 \\
0.000\end{array}$ & $\begin{array}{l}0.096 \\
0.000\end{array}$ \\
\hline Industry controls & & yes & yes & yes & yes \\
\hline Number of firms & & 2,594 & 12,122 & 2,594 & 12,122 \\
\hline
\end{tabular}

${ }^{1}$ The average marginal effect for firm size takes into account that firm size is included in the model in squares, too.

Note: All models include a constant; standard errors are based on robust estimates. 
Table 10 Decomposition of difference in the margins of exports in enterprises from manufacturing industries in East and West Germany 2010: Share of exports in sales

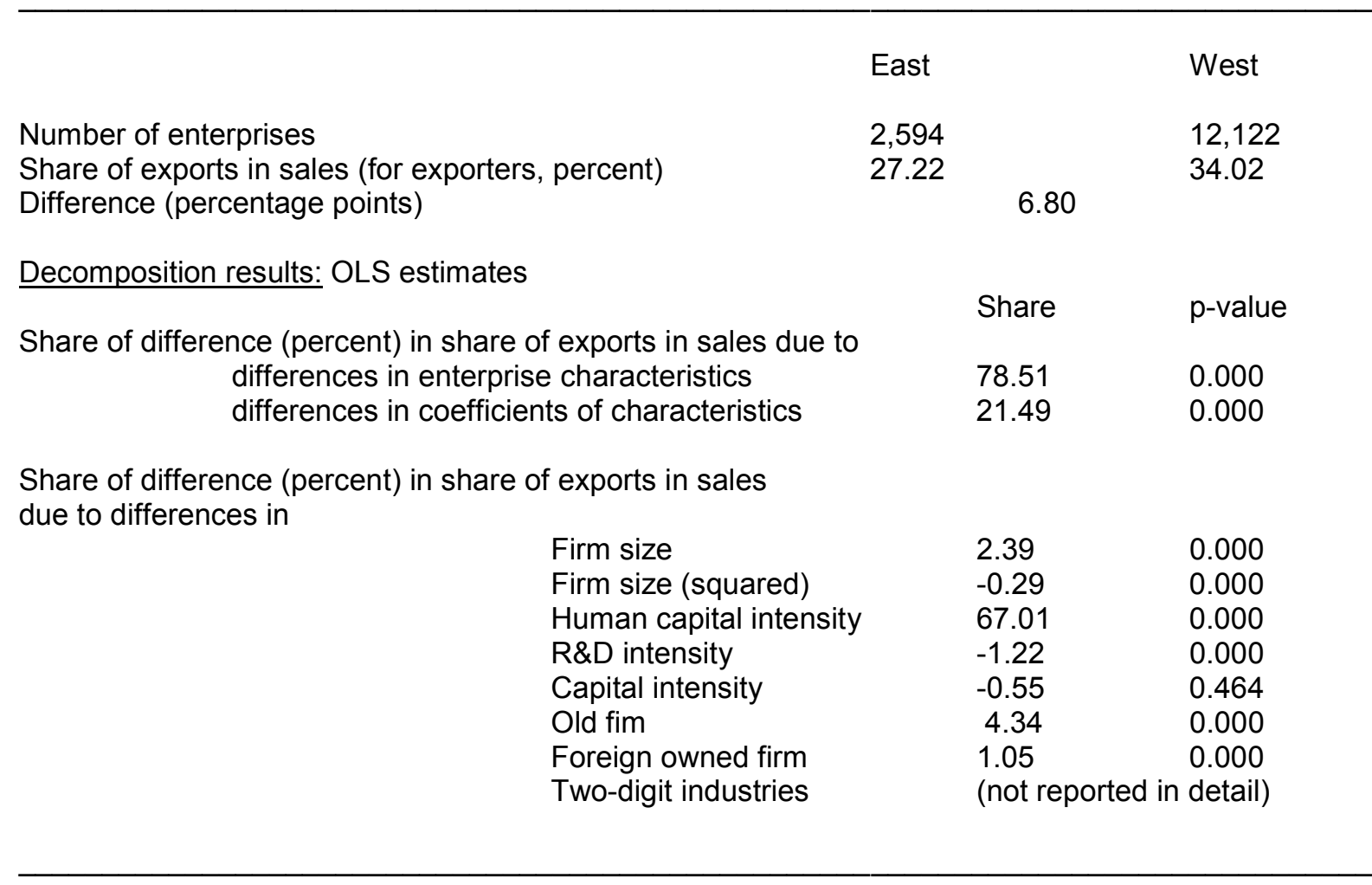

Note: The decomposition is based on estimates reported in Table 9 
Table 11: Determinants of margins of exports in enterprises from manufacturing industries in East and West Germany 2010: Number of destination countries

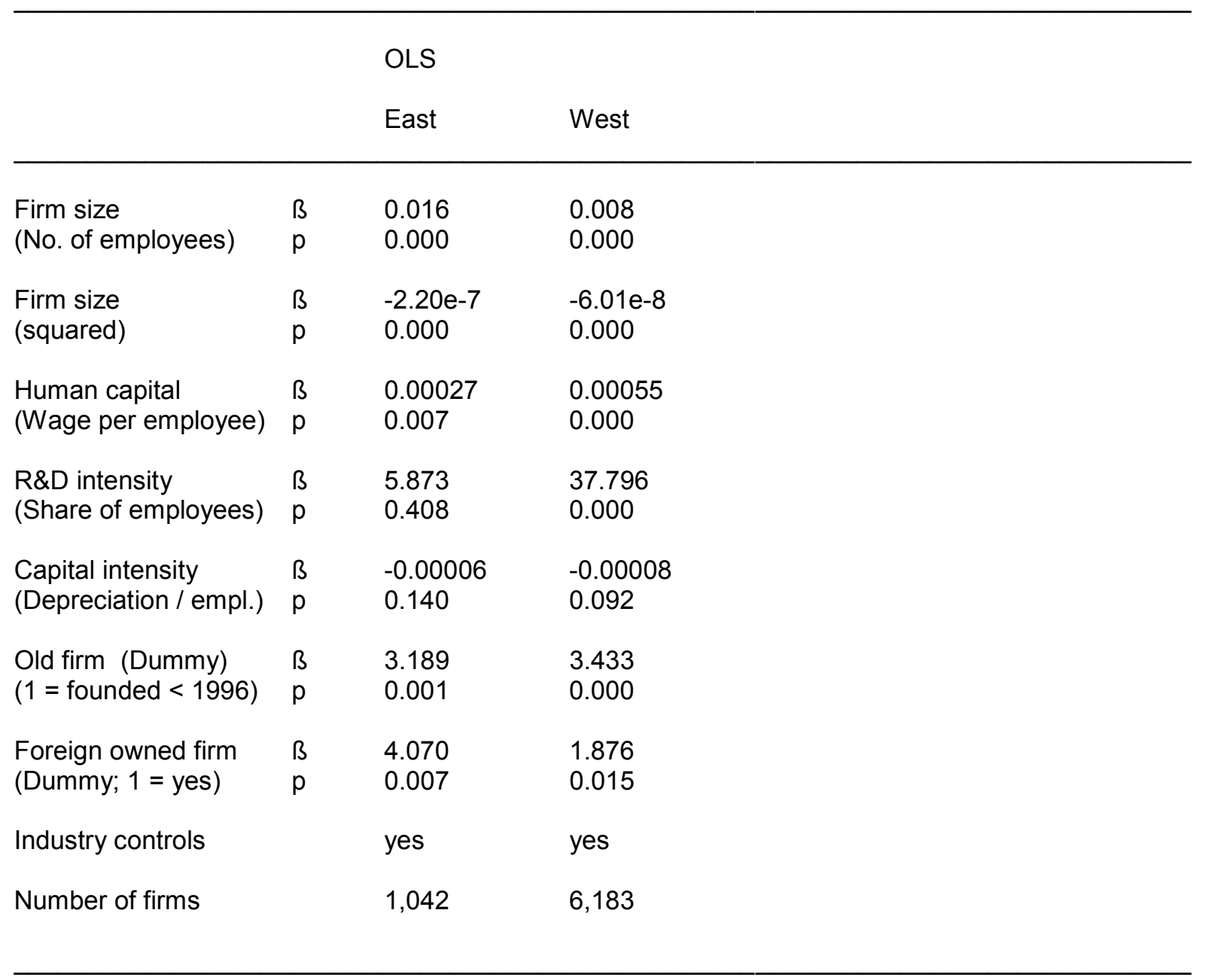

Note: All models include a constant; standard errors are based on robust estimates. 
Table 12: Decomposition of difference in the margins of exports in enterprises from manufacturing industries in East and West Germany 2010: Number of destination countries

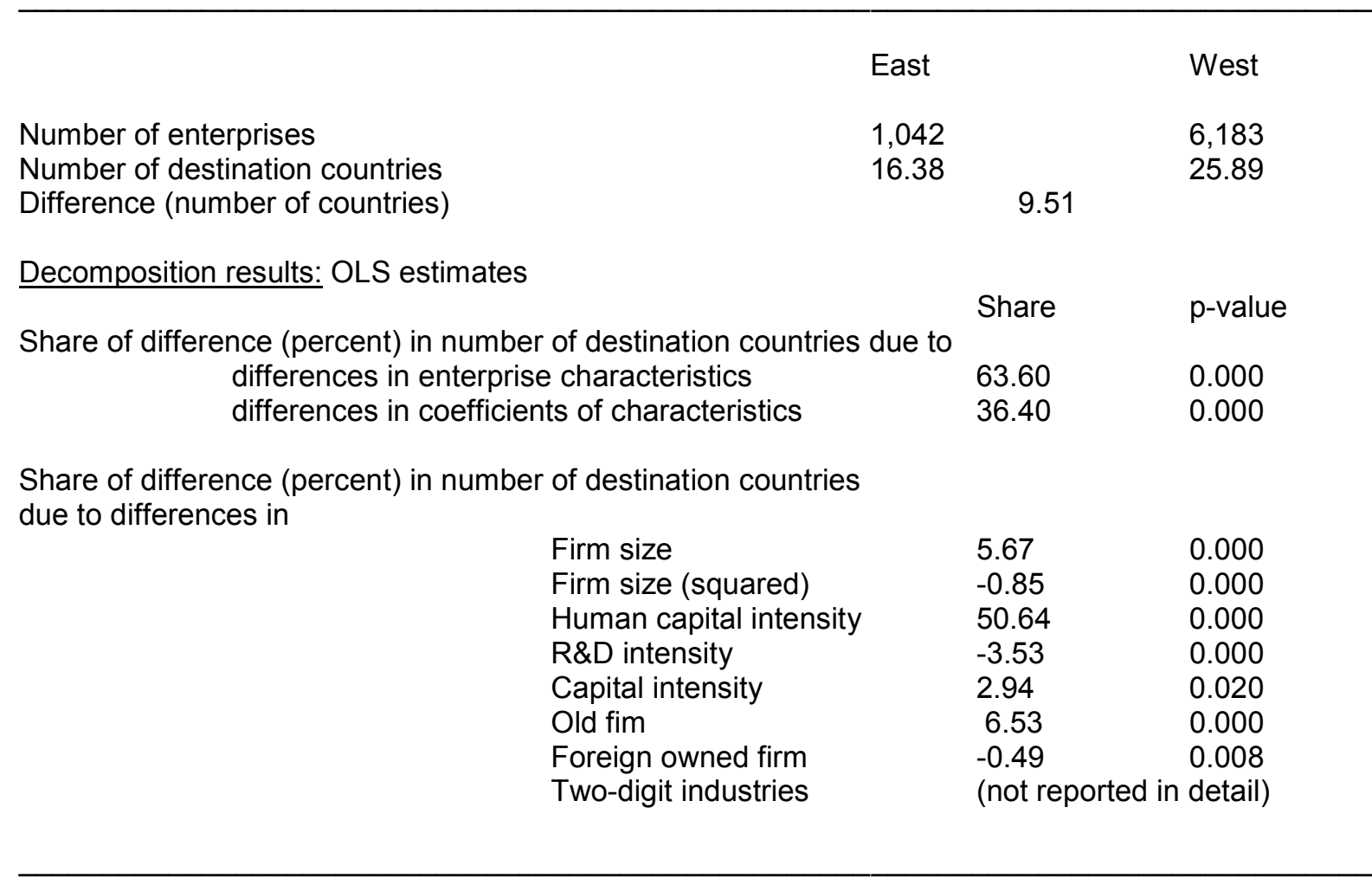

Note: The decomposition is based on estimated reported in Table 11. 
Table 13: Determinants of margins of exports in enterprises from manufacturing industries in East and West Germany 2010: Number of exported goods

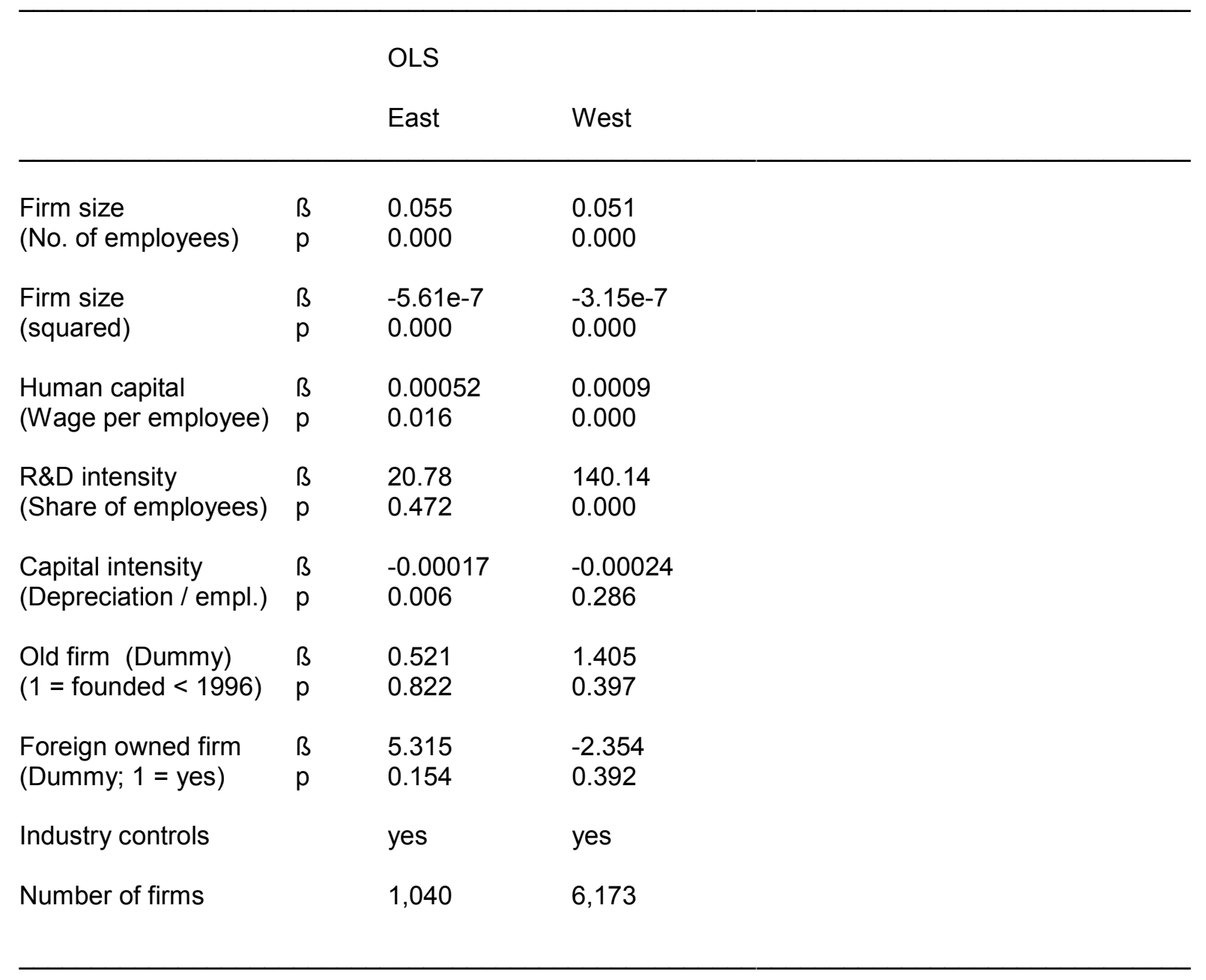

Note: All models include a constant; standard errors are based on robust estimates. 
Table 14: Decomposition of difference in the margins of exports in enterprises from manufacturing industries in East and West Germany 2010: Number of exported goods

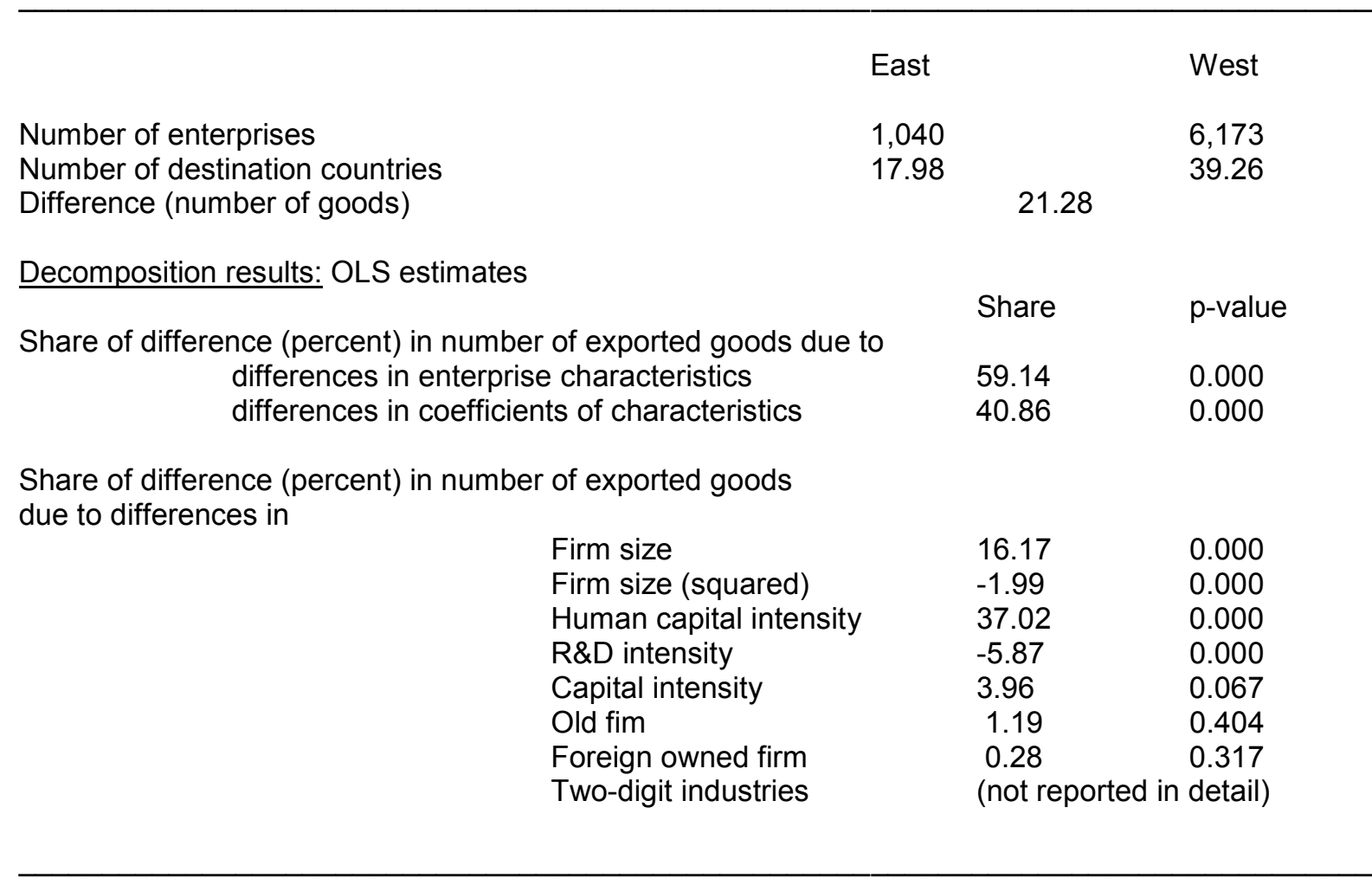

Note: The decomposition is based on estimates reported in Table 13. 


\section{Working Paper Series in Economics}

(recent issues)

No.312: Joachim Wagner: A note on the granular nature of imports in German manufacturing industries, October 2014

No.311: Nikolai Hoberg and Stefan Baumgärtner: Value pluralism, trade-offs and efficiencies, October 2014

No.310: Joachim Wagner: Exports, R\&D and Productivity: A test of the Bustos-model with enterprise data from France, Italy and Spain, October 2014

No.309: Thomas Wein: Preventing Margin Squeeze: An Unsolvable Puzzle for Competition Policy? The Case of the German Gasoline Market, September 2014

No.308: Joachim Wagner: Firm age and the margins of international trade: Comparable evidence from five European countries, September 2014

No.307: John P. Weche Gelübcke: Auslandskontrollierte Industrie- und Dienstleistungsunternehmen in Niedersachsen: Performancedifferentiale und Dynamik in Krisenzeiten, August 2014

No.306: Joachim Wagner: New Data from Official Statistics for Imports and Exports of Goods by German Enterprises, August 2014

No.305: Joachim Wagner: A note on firm age and the margins of imports: First evidence from Germany, August 2014

No.304: Jessica Ingenillem, Joachim Merz and Stefan Baumgärtner: Determinants and interactions of sustainability and risk management of commercial cattle farmers in Namibia, July 2014

No.303: Joachim Wagner: A note on firm age and the margins of exports: First evidence from Germany, July 2014

No.302: Joachim Wagner: A note on quality of a firm's exports and distance to destination countries: First evidence from Germany, July 2014

No.301: Ahmed Fayez Abdelgouad: Determinants of Using Fixed-term Contracts in the Egyptian Labor Market: Empirical Evidence from Manufacturing Firms Using World Bank FirmLevel Data for Egypt, July 2014

No.300: Annika Pape: Liability Rule Failures? Evidence from German Court Decisions, May 2014

No.299: Annika Pape: Law versus Economics? How should insurance intermediaries influence the insurance demand decision, June 2013

No.298: Joachim Wagner: Extensive Margins of Imports and Profitability: First Evidence for Manufacturing Enterprises in Germany, May 2014 [published in: Economics Bulletin 34 (2014), 3, 1669-1678]

No.297: Joachim Wagner: Is Export Diversification good for Profitability? First Evidence for Manufacturing Enterprises in Germany, March 2014 [published in: Applied Economics 46 (2014), 33, 4083-4090]

No.296: Joachim Wagner: Exports and Firm Profitability: Quality matters!, March 2014 [published in: Economics Bulletin 34 (2014), 3, 1644-1652] 
No.295: Joachim Wagner: What makes a high-quality exporter? Evidence from Germany, March 2014 [published in: Economics Bulletin 34 (2014), 2, 865-874]

No.294: Joachim Wagner: Credit constraints and margins of import: First evidence for German manufacturing enterprises, February 2014

No.293: Dirk Oberschachtsiek: Waiting to start a business venture. Empirical evidence on the determinants., February 2014

No.292: Joachim Wagner: Low-productive exporters are high-quality exporters. Evidence from Germany, February 2014 [published in: Economics Bulletin 34 (2014), 2, 745-756]

No.291: Institut für Volkswirtschaftslehre: Forschungsbericht 2013, Januar 2014

No.290: Stefan Baumgärtner, Moritz A. Drupp und Martin F. Quaas: Subsistence and substitutability in consumer preferences, December 2013

No.289: Dirk Oberschachtsiek: Human Capital Diversity and Entrepreneurship. Results from the regional individual skill dispersion nexus on self-employment activity., December 2013

No.288: Joachim Wagner and John P. Weche Gelübcke: Risk or Resilience? The Role of Trade Integration and Foreign Ownership for the Survival of German Enterprises during the Crisis 2008-2010, December 2013

No.287: Joachim Wagner: Credit constraints and exports: A survey of empirical studies using firm level data, December 2013

No.286: Toufic M. El Masri: Competition through Cooperation? The Case of the German Postal Market, October 2013

No.285: Toufic M. El Masri: Are New German Postal Providers Successful? Empirical Evidence Based on Unique Survey Data, October 2013

No.284: Andree Ehlert, Dirk Oberschachtsiek, and Stefan Prawda: Cost Containment and Managed Care: Evidence from German Macro Data, October 2013

No.283: Joachim Wagner and John P. Weche Gelübcke: Credit Constraints, Foreign Ownership, and Foreign Takeovers in Germany, September 2013

No.282: Joachim Wagner: Extensive margins of imports in The Great Import Recovery in Germany, 2009/2010, September 2013 [published in: Economics Bulletin 33 (2013), 4, 2732-2743]

No.281: Stefan Baumgärtner, Alexandra M. Klein, Denise Thiel, and Klara Winkler: Ramsey discounting of ecosystem services, August 2013

No.280: Antonia Arsova and Deniz Dilan Karamen Örsal: Likelihood-based panel cointegration test in the presence of a linear time trend and cross-sectional dependence, August 2013

No.279: Thomas Huth: Georg von Charasoff's Theory of Value, Capital and Prices of Production, June 2013

No.278: Yama Temouri and Joachim Wagner: Do outliers and unobserved heterogeneity explain the exporter productivity premium? Evidence from France, Germany and the United Kingdom, June 2013 [published in: Economics Bulletin, 33 (2013), 3, 1931-1940]

No.277: Horst Raff and Joachim Wagner: Foreign Ownership and the Extensive Margins of Exports: Evidence for Manufacturing Enterprises in Germany, June 2013 
No.276: Stephan Humpert: Gender Differences in Life Satisfaction and Social Participation, May 2013

No.275: Sören Enkelmann and Markus Leibrecht: Political Expenditure Cycles and Election Outcomes Evidence from Disaggregation of Public Expenditures by Economic Functions, May 2013

No.274: Sören Enkelmann: Government Popularity and the Economy First Evidence from German Micro Data, May 2013

No.273: Michael Berlemann, Soeren Enkelmann, and Torben Kuhlenkasper: Unraveling the Relationship between Presidential Approval and the Economy - A Multi-Dimensional Semi-Parametric Approach, May 2013

No.272: Michael Berlemann and Sören Enkelmann: The Economic Determinants of U.S. Presidential Approval - A Survey, May 2013

No.271: Soeren Enkelmann: Obama and the Macroeconomy Estimating Social Preferences Between Unemployment and Inflation, May 2013

No.270: Anja Köbrich León: Does Cultural Heritage affect Employment decisions - Empirical Evidence for Second Generation Immigrants in Germany, April 2013

No.269: Anja Köbrich León and Christian Pfeifer: Religious Activity, Risk Taking Preferences, and Financial Bahavior, April 2013

No.268: Anja Köbrich León: Religion and Economic Outcomes - Household Savings Bahavior in the USA, April 2013

No.267: John P. Weche Gelübcke and Isabella Wedl: Environmental Protection of Foreign Firms in Germany: Does the country of origin matter?, April 2013

No.266: Joachim Wagner: The Role of extensive margins of exports in The Great Export Recovery in Germany, 2009/2010, March 2013 [published in: Jahrbücher für Nationalökonomie und Statistik 234 (2014), 4, 519-526]

No.265: John-Oliver Engler and Stefan Baumgärtner: Model choice and size distribution: a Bayequentist approach, February 2013

No.264: Chiara Franco and John P. Weche Gelübcke: The death of German firms: What role for foreign direct investment?, February 2013

No.263: Joachim Wagner: Are low-productive exporters marginal exporters? Evidence from Germany, February 2013 [published in Economics Bulletin 33 (2013), 1, 467-481]

No.262: Sanne Hiller, Philipp J. H. Schröder, and Allan Sørensen: Export market exit and firm survival: theory and first evidence, January 2013

No.261: Institut für Volkswirtschaftslehre: Forschungsbericht 2012, Januar 2013

No.260: Alexander Vogel and Joachim Wagner: The Impact of R\&D Activities on Exports of German Business Services Enterprises : First Evidence from a continuous treatment approach, December 2012

No.259: Christian Pfeifer: Base Salaries, Bonus Payments, and Work Absence among Managers in a German Company, December 2012 


\section{Leuphana Universität Lüneburg}

Institut für Volkswirtschaftslehre

Postfach 2440

D-21314 Lüneburg

Tel.: ++49 41316772321

email: brodt@leuphana.de

www.leuphana.de/institute/ivwl/publikationen/working-papers.html 